\title{
The interaction between primary teachers' perceptions of ICT and their pedagogy
}

\author{
Avril M. Loveless \\ School of Education, University of Brighton, Falmer, Brighton, BN1 9PH, UK; \\ aml@brighton.ac.ukalmer, Brighton
}

\begin{abstract}
A qualitative, case study approach was used to investigate the perceptions and pedagogy of a small group of teachers working within one school, Carberry Junior School in England. The study was carried out during an eighteen-month period of significant change in primary schools responding to the UK Government's National Grid for Learning (NGfL) initiative and its impact on models of access to ICT resources and expectations in teaching and pupil achievement. The paper highlights the teachers' perceptions of Information and Communication Technology (ICT) as a social and cultural phenomenon, as an ambiguous area constructed as a discrete subject, curriculum resource and higher-order capability, and as a "new" field in primary schools. An interactive model is proposed to describe the interaction of the teachers' perceptions and pedagogy. The case study can offer insight to a consideration of professional development with ICT in primary schools during a period of rapid change in resource provision and expectations of teachers' use of ICT to support teaching and learning.
\end{abstract}

Key words: elementary education, social contexts, research, professional development, change

\section{INTRODUCTION}

Teachers of young children engage with new information and communication technologies within wide social and cultural contexts. In the United Kingdom they work with a range of ambiguous constructions of subject knowledge of ICT capability that underpin educational policy expressed in the National Curriculum, and expectations of teacher training and professional development. A case study was conducted in an English

The original version of this chapter was revised: The copyright line was incorrect. This has been corrected. The Erratum to this chapter is available at DOI: 10.1007/978-0-387-35668-6_17 
Junior School at a time of transition and change. The UK initiative for the National Grid for Learning provided opportunities for new models of access to ICT resources within the school, and raised expectations of teachers' competence and confidence in the use of ICT to support subject teaching. The analysis focused on the interaction between perceptions of ICT and pedagogy as an expression of dimensions of professional knowledge.

\section{THE CONTEXTS FOR THE STUDY}

\subsection{Social and cultural contexts}

The social and cultural contexts in which ICT resources are perceived and used by teachers are key influences in the development of a range of personal and professional practices. Anxieties are expressed about new visions of the post-industrial society, how we learn to adapt to new labour patterns in our society, and how ICT can be used for controlling information, surveillance, marketing, and invasions of privacy. There are wider and often contradictory underlying perceptions of technology in contemporary Western society in two dominant paradigms of technological and social determinism. The debates form a backdrop to the development and expression of teachers' perceptions of the role of ICT in their professional work.

\subsection{Perspectives on ICT capability}

A concept of "ICT capability" is central to teachers' work within the framework of the Statutory National Curriculum which underpins planning, coordination and presentation of the curriculum, assessment and pupils' achievements (Department for Education and Employment 1999). The term is ambiguous in government curriculum policy, reflecting different and developing aims and intentions. Given some of the ambiguities and changes in definition and focus of ICT capability, it is difficult to predict primary teachers' perceptions of ICT capability and its role in learning.

\subsection{Teachers' perceptions and beliefs about ICT}

A study of the influence of teachers' perceptions and beliefs about ICT in their practice identifies two types of approaches: (1) the computer awareness approach that recognises the ubiquity of ICT in wider society and (2) the pedagogic approach that uses ICT to facilitate teaching and learning objectives (Drenoyianni and Selwood 1998). The majority of the teachers 
questioned indicated a computer awareness approach, and even some of those teachers expressing a pedagogic approach demonstrated discrepancies between their statements and their classroom practice. That practice focused on computer skills rather than integrated learning intentions. Changes in practice often related more to issues of management and organisation than to learning and assessment objectives. The study raises questions about what created and reinforced the beliefs that underlie different practices and the possible confusion in official documentation and guidance, indicating a lack of consensus and understanding of a conceptual framework for ICT in education.

Teachers' perceptions of ICT in education are not only influenced by official documents and guidelines, but also by their own experiences of using ICT for personal reasons in a social and professional context where the profile of and access to ICT resources is fast-changing. Dawes' study (1999) investigating key factors enabling teachers to acquire "network literacy" identified, not a model of teacher deficit and resistance, but a pragmatic approach to change as the new ICT resources were being incorporated into school practice

\subsection{Models of professional knowledge}

Descriptions and discussions of pedagogy as an expression of teachers' professional knowledge have developed in both breadth and subtlety, acknowledging developments in understandings of the contexts and content of learning and teaching (Watkins and Mortimore 1999). The strands of subject knowledge, pedagogical representation, personal beliefs and values, and the context of situated learning are woven together into a dynamic and interactive model of teacher professional knowledge proposed by Banks, Leach and Moon (1999). Teachers learn to be teachers in situations that are relevant and authentic. A development of the model highlights the interactions between subject knowledge, pedagogical content knowledge, pedagogic knowledge, identity and community that are held in tension by the teachers' experiences of, and reflections upon, change in their practice (Loveless 2001).

\section{RESEARCH METHODOLOGY}

At Carberry Junior School (CJS), the teachers taught all aspects of the National Curriculum to children aged 7 to 11 years (Key Stage 2). Inspection reports described the children attending the school as presenting an "average" profile, demonstrating the full range of attainments expected for 
that Key Stage. The quality of teaching in the school was described as "high" by local education authority advisors. There was a positive ethos in school development, an innovative approach to the development of ICT in the school and an open attitude to involvement in research.

The research methods used to explore the teachers' perceptions of ICT and pedagogical practices used the ethnographic techniques of in-depth interviews with teachers, observation of classroom practice, narrative descriptions and use of written material such as school documentation. The study presented an analysis of the teachers' perceptions and professional knowledge.

\section{TEACHERS' PERCEPTIONS OF ICT}

"Perceptions of ICT" was grouped into three sub-themes: Perceptions of ICT in society, perceptions of ICT capability and perceptions of ICT in schools.

\subsection{Perceptions of ICT: Its impact on society}

The Information Society was portrayed as inevitable and pervasive, focused on economic and social change, and closely associated with issues of participation in the future development of society. As well as descriptions of the future involving excitement, change, opportunity and progress, the teachers also presented images of the "Information Society" as sources of anxiety and concern. They expressed the need to "keep up" with the cultural phenomena of irrevocability and rapid change. They tended to accept the view of children's "inherent computer capabilities" without critique, and discussed their general concerns about entitlement, equity and their professional responsibilities towards equipping the children for the future. Concerns about access to computers and information for "haves and have nots" were expressed.

The children's access to ICT at home was a significant issue and the school was seen as playing an important role in providing equal access to the facilities. No detailed discussion of the types of experiences that children might have with ICT out of school, nor the implications of literacy, culture and content described by commentators on the "Digital Divide" occurred.

Concern emerged about the demands placed upon teachers to keep up with the changes in technology, and the children's understanding and use. Another issue was the expectation for teachers to deliver a curriculum that would equip children for the future. 
Three teachers used phrases such as: "We owe it to the children to give them a good start," and "You've got to overcome your own personal feelings and do it, otherwise you'll feel that you are short changing the children," and "They'd be at a huge disadvantage. The children are going to suffer. They are going to need it in life." Those expressions of the importance of ICT competence for the children's future participation, rather than their immediate learning needs, also echo those of parents and teachers in Downes study (1998).

\subsection{Teachers' perceptions of ICT capability}

Teachers" perceptions of ICT capability as "subject" or "tool" or "capability" were not clearly distinguished and should not be considered as mutually exclusive categories. The confusion and ambiguity were admitted openly and the teachers described their attempts to weave the strands together to make connections between ICT as a discrete subject and a crosscurricular tool. Teachers perceived the importance of teaching the children to acquire the skills for using ICT resources. The need for younger children to be well grounded in skills was reinforced and the discrete nature of the direct teaching of skills and techniques was also described.

Closely linked was the perception of ICT as a distinct subject domain given priority in curriculum policy and resource provision. One teacher emphatically said, "It's also a tool for all the others (curriculum areas), but you can't use it effectively as a tool for the others until you have learned it as a subject in its own right."

ICT was likened to music or physical education, subjects that required the teacher to have "specialist" knowledge, skills and understanding. ICT capability as a subject was not viewed as a collection of discrete skills, techniques and processes. Teachers perceived ways ICT could be embedded in the context of other subjects and used as a tool to support learning and teaching.

Some curriculum subjects were considered to be more appropriately supported by ICT than others, although there was little consensus about what these might be! In trying to explain the experience of perceiving ICT as a subject and a tool in the curriculum, one of the teachers summarised the issue that she felt she faced in dealing with the two perspectives in her own practice:

It's a lot easier to teach it as a subject, just like using the skills that you have to do but it's a lot more fun when they see where it links in. 


\subsection{Teachers' perceptions of ICT in schools}

After thirty years of government ICT strategies, teachers described the application of ICT in the primary school as "new" and "rapidly changing". Teachers' resistance and resilience to technological change has been vividly described by a number of researchers and commentators (Selwyn 1999). But other researchers describe teachers' pragmatic reasons for not using new technologies: Motivation is low when classroom resources are limited, and the curriculum and assessment framework does not require high status/high stakes contributions of ICT (Watson 1997; Dawes 1999).

The NGfL provision of networked resources in schools and the requirement for ICT development plans contributed to perceptions of change in resources for teaching and learning. Teachers saw ICT as a new experience, unrelated to previous attempts to implement the National Curriculum for ICT. Their descriptions of ICT in schools as "new" and a "new subject" were related much more closely to their personal experiences of using ICT at home and in school in meaningful and successful ways than to the twelve years of National Curriculum Programmes of Study.

The teachers reported recent changes in their own use and attitudes when they had flexible access to ICT at appropriate times, usually at home. They recognised the increased access that the children had outside school. So perceptions of ICT in schools seemed to be influenced by the nature of the activities that ICT facilitated: Standardised applications, communications and whole class access (which were authentic in the teachers' own experience of planning, preparing and implementing relevant learning activities for the children).

The teachers' visions of how classrooms might change in the next ten years also gave insights into their perceptions of ICT in schools. Despite the predictions of classrooms without walls and the networked teacher engaging with knowledge and learners in different ways (Scrimshaw 1997), the future visions of the teachers were conservative. Their predictions of the effect of ICT on the nature of their work in the next ten years related to classrooms equipped with more resources rather than different models of interaction with learners and knowledge. Some expressed anxiety about a dystopian view of the future with technology balanced by a sceptical view of the resistance to change within the school system. One teacher considered that the "... side of teaching which is important is the social skills, having someone there to ask", and did not want to teach from home via a web site. Her colleague was more concerned that change in schools would not reflect the potential of ICT for supporting new strategies for learning and teaching. She described her vision of ".. lots and lots of activities. Things would be set up and the children would be more familiar with them and able to access 
things by themselves and get on by themselves, but then some classrooms I'm sure would be just the same!"

\section{INTERACTIONS BETWEEN PRIMARY TEACHERS' PERCEPTIONS OF ICT AND THEIR PEDAGOGY}

Perceptions of ICT are fashioned by the teachers' identity and participation in wider cultural and social spheres that influence the professional arenas and settings in which they practice. Their perceptions reflect the ongoing negotiations of meanings of ICT as they work with young children. As students and teachers reflect upon their constructions of ICT and their own knowledge, skills and understanding, it is important to encourage their awareness of the ambiguities and different perspectives in trying to define ICT. They need not see them as sources of anxiety but can learn to hold them in tension. They can develop a range of practices: A focus on techniques and applications; the use of ICT resources to support specific learning objectives; the development of higher-order thinking; collaboration and communication with the appropriate use of ICT tools and media.

Models of professional development need to recognise how teachers' perceptions of the purpose and potential of ICT are grounded in a sociocultural context. Current models of Initial Teacher Training and Continuing Professional Development for ICT are ostensibly linked to pedagogic practice, but often lack the sense of trajectory for teachers. Instead the models focus on evidence of competence rather than confidence in change, and do not draw upon a mutual interaction between experiences in home and school contexts. Developing confidence in the use of ICT is high stakes for those who regard it as an integral part of their identity as teachers with responsibilities for their pupils' short term achievement in statutory assessment and long term participation in an Information Society.

\section{REFERENCES}

Banks, F., Leach, J., and Moon, B. (1999) New understandings of teachers' pedagogic knowledge. In J. Leach and B. Moon (eds.) Learners and Pedagogy. London: Paul Chapman Publishing in association with The Open University Press.

Dawes, L. (1999) First connections: Teachers and the National Grid for Learning. Computers and Education 334235 - 252.

Department for Education and Employment. (1999) The National Curriculum for England: Information and Communication Technology. London: DfEE. 
Downes, T. (1998) Children's use of computers in their homes. Unpublished Ph.D. thesis. Sydney: University of Western Sidney.

Drenoyianni, H. and Selwood, I. D. (1998) Conceptions or misconceptions? Primary teachers' perceptions and use of computers in the classroom. Education and Information Technologies 3 87-99.

Loveless, A. M. (2001) The interaction between primary teachers' perceptions of information and communication technology (ICT) and pedagogy. Unpublished Ph.D. thesis. Brighton: University of Brighton.

Scrimshaw, P. (1997) Computers and the teachers' role. In B. Somekh and N. Davis (eds.) Using Information Technology Effectively in Teaching and Learning. London: Routledge.

Selwyn, N. (1999) Why the computer is not dominating schools: A failure of policy or a failure of practice? Cambridge Journal of Education 29177 - 91.

Watkins, C. and Mortimore, P. (1999). Pedagogy: What do we know? In P. Mortimore (ed.) Understanding Pedagogy and Its Impact on Learning. London: Paul Chapman Publishing.

Watson, D. (1997) A dichotomy of purpose: The effect on teachers of government initiatives in Information Technology. In B. Samways and D. Passey (eds.) IT Supporting Change through Teacher Education: Proceedings of the IFIP Joint Conference of Working Group 3.1 and 3.5, Israel. London: Chapman \& Hall.

\section{BIOGRAPHY}

Avril M. Loveless is a Principal Lecturer in ICT in Education at the University of Brighton, UK. She has published a number of books and articles relating to the use of ICT in learning and teaching, focusing on Primary Education. Her current research interests include pedagogy and ICT, and the creative use of digital technologies. She has been the chair of the Association for Information Technology in Teacher Education and is the currently the editor of the Journal of IT for Teacher Education. She is the chair of Creating Spaces, a network of independent professionals promoting creative uses of technology. She is a member of IFIP's Working Group 3.5. 